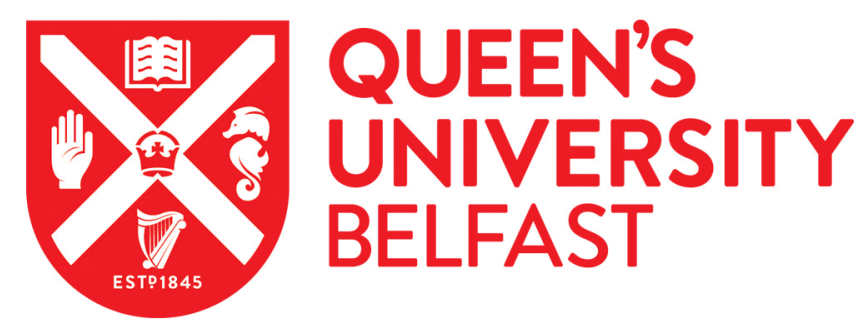

\title{
Inequalities in English child protection practice under austerity: A universal challenge?
}

Bywaters, P., Brady, G., Bunting, L., featherstone, B., Jones, C., Morris, K., Scourfield, J., Sparks, T., \& Webb, C. (2017). Inequalities in English child protection practice under austerity: A universal challenge? Child and Family Social Work. https://doi.org/10.1111/cfs.12383

Published in:

Child and Family Social Work

Document Version:

Peer reviewed version

Queen's University Belfast - Research Portal:

Link to publication record in Queen's University Belfast Research Portal

Publisher rights

(C) 2017 John Wiley \& Sons Ltd. This work is made available online in accordance with the publisher's policies. Please refer to any applicable terms of use of the publisher.

\section{General rights}

Copyright for the publications made accessible via the Queen's University Belfast Research Portal is retained by the author(s) and / or other copyright owners and it is a condition of accessing these publications that users recognise and abide by the legal requirements associated with these rights.

Take down policy

The Research Portal is Queen's institutional repository that provides access to Queen's research output. Every effort has been made to ensure that content in the Research Portal does not infringe any person's rights, or applicable UK laws. If you discover content in the Research Portal that you believe breaches copyright or violates any law, please contact openaccess@qub.ac.uk. 
FINAL DRAFT awaiting publication. Do not quote or circulate without permission.

\section{Inequalities in English child protection practice under austerity: a universal challenge?}

Bywaters, P., Brady, G., Bunting, L., Daniel, B., Featherstone, B., Jones, C., Morris, K, Scourfield, J., Sparks, T., Webb, C.

\section{Acknowledgements:}

The authors wish to acknowledge the support of the Nuffield Foundation which funded the work reported here. The Nuffield Foundation is an endowed charitable trust that aims to improve social well-being in the widest sense. It funds research and innovation in education and social policy and also works to build capacity in education, science and social science research. The views expressed are those of the authors and not necessarily those of the Foundation. More information is available at www.nuffieldfoundation.org 
FINAL DRAFT awaiting publication. Do not quote or circulate without permission.

\section{Inequalities in English child protection practice under austerity: a universal challenge?}

\section{Abstract}

The role that area deprivation, family poverty and austerity policies play in the demand for and supply of children's services has been a contested issue in England in recent years. These relationships have begun to be explored through the concept of inequalities in child welfare, in parallel to the established fields of inequalities in education and health. This article focuses on the relationship between economic inequality and out-of-home care and child protection interventions. The work scales up a pilot study in the West Midlands to an all-England sample, representative of English regions and different levels of deprivation at a local authority (LA) level. The analysis evidences a strong relationship between deprivation and intervention rates and large inequalities between ethnic categories. There is further evidence of the inverse intervention law (Bywaters et al., 2015): for any given level of neighbourhood deprivation, higher rates of child welfare interventions are found in LAs which are less deprived overall. These patterns are taking place in the context of cuts in spending on English children's services between 2010-11 and 2014-15 that have been greatest in more deprived LAs. Implications for policy and practice to reduce such inequalities are suggested.

\section{Introduction}

Of 35 OECD countries, the UK had the $29^{\text {th }}$ highest rate of disposable income inequality in 2014 (OECD, 2016). Only Estonia amongst European countries had a higher Gini coefficient - a measure of the distribution of wealth in a society, wherein a higher score means higher levels of inequality. The period since the global financial crisis of 2007 has seen some economic recovery but, as the OECD reports, the benefits have not been equally shared. The United Kingdom is identified as one of the countries where - although job creation has been strong - real wages have fallen. In the UK the redistributive effects of taxation and benefits are amongst the weakest in Europe while non-cash transfers in the form of public spending on health, education and social care have failed to keep pace with inflation since 2010. What relationship have these economic trends had with patterns of demand for and supply of children's services?

In the case of children's social care in England, our analysis of LA expenditure returns to the Department for Education (DfE) shows a total reduction in expenditure per child on Children's and Young People's Services of 14\% between 2010 and 2015 (at 2015/16 prices), with the most deprived third of LAs (by overall Index of Multiple Deprivation score) being cut by $21 \%$ compared to $7 \%$ in the least deprived third. The heaviest burden of these cuts have fallen on early years and early help services. The DfE report on 'Children's services: spending and delivery' (2016) shows that expenditure on services other than those for children in need, looked after children and adoption was cut by $29 \%$, nationally, between $2010 / 11$ and 2013/14 alone. They concluded that

'spending on some services areas was difficult or impossible for participating councils to change, ... as for looked after children. ... (H)owever local councils had greater flexibility to decide spending changes on other areas, such as children's services early help' (p.14).

The DfE provide no analysis of data by the level of deprivation of the LA. Paradoxically they also concluded that the major strategy LAs used for managing demand was to place greater emphasis on early help and integrating services, the reality not matching the rhetoric. Our examination shows that, as a result of this pattern of cuts, by 2014-15 LAs were spending $41 \%$ of the total children's services budget on looked after children (in out-of-home care), on average, compared to only $32 \%$ in 2010/11. Inequalities had opened up between LAs with high deprivation LAs spending $44 \%$ on 
FINAL DRAFT awaiting publication. Do not quote or circulate without permission.

looked-after children, compared to $39 \%$ in low deprivation LAs, further illustrating the acute squeeze on prevention and family support especially in deprived areas.

As austerity policies were eating into the capacity of both families and LAs to provide for children's wellbeing, and the narrative around child protection became more risk averse (Featherstone et al., 2014; Stanford, 2010), it is not surprising that levels of service demand were increasing. Between 2010 and 2016 the numbers of children in contact with state services during the year increased substantially.

Insert Table 1

These changing patterns of service demand were not only influenced by economic factors but also by the culture surrounding children's services. The vision of 'a community based and family oriented service, ... available to all. ... reach(ing) far beyond the discovery and rescue of social casualties' (Seebohm 1969, p. ) was, of course, long gone (Parton, 2014). It had been replaced by a form of state intervention in family life still predominantly based in local government and dependent on social work professionals but saturated by a focus on child protection. The model being promoted centred on the identification of and elimination of risk to individual children with little concept of the relationship of safeguarding to the economic or community context let alone the principle of reciprocity that Seebohm had proposed (Featherstone et al. 2014). While LAs had some capacity to contain the growth of accepted referrals and there was little increase, once referred children (or families) were increasingly likely to be subject to a Section 47 investigation. A section 47 investigation takes place where the LA has 'reasonable cause to suspect that a child who lives, or is found, in their area is suffering, or is likely to suffer, significant harm'. By 2015-16 more than 1 in 4 of all referrals were investigated as a child protection concern compared to 1 in 7 in 2009-10, but the proportion investigated that were substantiated by a child protection plan had fallen by $20 \%$.

Insert Table 2

In the face of austerity policies affecting families and local government, powerful political and professional voices have emphasised the individual responsibility of parents and LAs in children's welfare. The role of families' economic circumstances in child protection was repudiated by the Secretary of State with responsibility for children's services.

'In too many cases, social work training involves idealistic students being ... encouraged to see these individuals as victims of social injustice whose fate is overwhelmingly decreed by the economic forces and inherent inequalities which scar our society. This analysis is, sadly, as widespread as it is pernicious. It robs individuals of the power of agency and breaks the link between an individual's actions and the consequences. It risks explaining away substance abuse, domestic violence and personal irresponsibility, rather than doing away with them' (Gove, 2013).

A report commissioned by government on the education of social workers (Narey, 2014) also challenged the link between family circumstances and outcomes for children:

'many families of modest income provide loving and safe homes for their children and it is vital - I would argue - not to seek to persuade students that poor parenting or neglect are necessary consequences of disadvantage. There may be a partial correlation between disadvantage and poor parenting but there is not a causal link' ( $p .11)$.

Similarly the performance of LAs has been said to be nothing to do with either the influence of the level of deprivation on demand or the level of expenditure. For example, Michael Wilshaw, then 
FINAL DRAFT awaiting publication. Do not quote or circulate without permission.

Chief Inspector of Ofsted, wrote in his final annual report on children's services (Ofsted, 2016, p. 5 ), referring to the $25 \%$ LAs judged inadequate, that

'these weaknesses can be overcome through grit and determination and with good leaders, who make the work easier to do well. Our inspectors have seen this across the country and we now know that: Inadequacy is not a function of size, deprivation or funding, but of the quality of leadership and management'.

The report of the National Audit Office (NAO) into Children in Need (2016, p. 7) reported that, 'Our own analysis found no relationship between LAs' reported spending on each child in need and the quality of service' as measured by Ofsted judgements. However, in fact, both high deprivation and low per child expenditure have a significant relationship to poor Ofsted judgements (see below, p.10).

These arguments focused on whether variations in service provision between LAs reflected deprivation or expenditure. The wider issue of differences between LAs in intervention rates has been the subject of some attention in recent years and begun to be characterised as an issue of social inequality (Bywaters, 2016; Bywaters et al., 2014; 2016a) echoing inequalities in children's education and health. This approach was adopted by the NAO report, emphasising that wide inconsistencies between LAs in Ofsted judgements, re-referral and repeat child protection plan rates were evidence that 'children in different parts of the country do not get the same access to help or protection' (p.7). Indeed, the NAO report charged the DfE with reconciling variations in LA practice with 'its goal of all children having equal access to high-quality services' ( $p .10$, authors' emphasis).

The DfE's blueprint for improving children's services published in the summer of 2016, 'Putting Children First' did, indeed, imply that equality of access to service provision was a central goal of policy: 'By 2020 our ambition is that all vulnerable children, no matter where they live, receive the same high quality of care and support' (p.12). This commitment to equality of access to services, coupled with the pre-existing aims of closing the gap in outcomes between looked after children and the wider population, could be taken as an equalities perspective gaining a foothold in English children's services policy.

However, for an equalities perspective to become convincing, equality of access to services for children whose development is already under threat has to be extended to equality in children's chances of a good enough childhood, and equality of outcomes for all children in contact with services, not only those who are looked after. For these aims to be achieved the system needs to know, first, who is entering contact with children's services and why. Which children, from families in which circumstances, from which communities, in which neighbourhoods are experiencing damaging childhoods? Second, there is a need to understand what happens to the majority of children who receive a children's services intervention short of becoming looked after or adopted. For example, what are the consequences for families' 'confidence in turning to professionals for help' (DfE, 2016, p.70) of the exponential growth in Section 47 investigations which do not result in child protection plans?

The first of these issues has been central to a research study funded by the Nuffield Foundation. The Child Welfare Inequalities Project (www.coventry.ac.uk/CWIP) aimed to build knowledge and understanding of inequalities in children's chances of involvement with children's services between the four UK countries: England, Northern Ireland, Scotland and Wales and between LAs within each of the four countries. A pilot study in the English West Midlands, covering $10 \%$ of all children in the country but all from one region, had found large scale inequalities in the proportion of children from different LAs that were either on a child protection plan or were a looked after child on $31^{\text {st }}$ March 2012 (Bywaters et al., 2014; 2015; 2016a; 2016b). The main factors correlating with these 
FINAL DRAFT awaiting publication. Do not quote or circulate without permission.

inequalities were deprivation level in the immediate neighbourhood (a proxy for family socioeconomic circumstances), ethnic category and the overall deprivation of the LA. Within the 4 nations study, a quantitative study of a representative sample of English LAs was undertaken and key findings of this element of the wider project are outlined below.

A central purpose of the project was to test the 'demand and supply' model of inequalities in intervention rates published previously (Bywaters et al., 2015). Once inconsistencies in the data have been eliminated, we suggest that intervention rates are a product of two main factors which we call 'demand' and 'supply'. Demand refers to the underlying social determinants such as the socioeconomic circumstances of families, which may get reflected in levels of domestic violence, mental and physical ill-health or substance use, and possibly also the impact of social capital in terms of the quality of neighbourhoods and communities. Supply factors are those factors affecting service provision and patterns, such as the legal and policy framework, the local priorities and patterns of service provision, the level and allocation of resources; the skills and qualities of staff. Our hypothesis is that supply and demand factors interact to produce intervention rates.

Insert Fig. 1 here

\section{Methods}

The Child Welfare Inequalities Project, a collaboration between researchers in 7 universities in all the UK countries, adopted an integrated methodology involving a combination of:

- literature based analyses of policy and evidence

- quantitative studies in each country and

- in depth case studies of policy and practice in a small number of LAs in England and Scotland, supplemented by focus groups in Wales and Northern Ireland.

These core elements will be enhanced by a study of parental perspectives, to be undertaken in 2017 .

The literature based studies took a number of forms. A rapid evidence review of the relationship between poverty and child abuse and neglect was jointly commissioned by the Nuffield Foundation and the Joseph Rowntree Foundation and published in 2016 (Bywaters et al., 2016c). Two parallel studies of the policy context in the four UK countries linked to trends in intervention rates were carried out focusing on children on child protection plans or registers and on looked after children, respectively (Bunting et al., forthcoming; McGhee et al., forthcoming). The in-depth case studies will be reported elsewhere.

The focus here is on the quantitative study in England. The design involved administrative data linkage between three data sets:

- data about individual children obtained from LAs based on the annual children in need and looked after children returns required by the DfE

- population data about the numbers of children aged 0-17 living in England, at different levels of geography, using publicly available data from the Census 2011 and mid-year population estimates for summer 2014

- Index of Multiple Deprivation scores (2015) at different levels of geography (https://www.gov.uk/government/statistics/english-indices-of-deprivation-2015).

The children's services data covered aspects of the identities of all children who were in need at the $31^{\text {st }}$ March 2015: their age, gender, ethnic category; whether they were on a child protection plan (and, if so, under which category of abuse) or whether they were looked after (and if so, where they were placed and their legal status). All these data are routinely provided by LAs to the DfE. The additional item of data requested, which is not provided in the children in need census, concerned the small neighbourhood (Lower Super Output Area - LSOA) in which they lived or from which they 
FINAL DRAFT awaiting publication. Do not quote or circulate without permission.

entered the care system, if they were a looked after child. The purpose of this was to link their family to a neighbourhood deprivation score.

The linking of family addresses to LSOA deprivation scores was employed as a proxy measure for family socio-economic circumstances. Surprisingly, the DfE data collection on children's services, while comprehensive and of high quality in many respects, includes no data about the circumstances of parents. Nothing is recorded, reported or analysed systematically about family circumstances such as parental income and wealth, housing conditions, educational background, health, age, marital or employment status. The claim in Putting Children First (p.27) that 'we know a lot about the (children's) family life, their experiences and the challenges they are facing' is not supported by the evidence (Bywaters et al., 2016c). In fact, almost nothing is known at the population level. Linkage to education data about whether children in the school system are entitled to free school meals - as a measure of family socio-economic status - is in its infancy and could only provide a binary distinction between being entitled or not entitled.

LSOAs are small geographical areas with an average population of around 1600 , roughly a quarter of whom are likely to be under 18. The more than 32,000 LSOAs in England each have an Index of Multiple Deprivation score which reflects 7 domains and multiple measures, of which income and employment levels are the most heavily weighted. The measure is not used here as an indicator of the qualities of the neighbourhoods as a contributor to child development, for example, the level of informal or formal social support available, but as an indicator of family circumstances. Clearly there are limitations to this model as each small neighbourhood will contain a range of families but in the absence of direct data about families and over a large sample size both in terms of LSOAs $(4,115)$ and children $(14,400)$ this methodology offers a widely used mechanism for linking socio-economic factors with inputs and outcomes ((Jordan et al., 2004; Conrad, 2012; Brown et al., 2010).

Ethical approval for the work was obtained from the Association of Directors of Children's Services Research Group and from Coventry University's Faculty Research Ethics Committee. Further safeguards in accessing and handling the data were negotiated on a case by case basis with individual LAs.

Reflecting the aim of securing a representative sample of English data, the objectives of the sampling frame were to obtain information:

- On more than $10 \%$ of all children in England, including a minimum of $10 \%$ of children from each of the five broad ethnic categories used for administrative purposes

- From 2 LAs in each of the 10 English regions, 20 in all out of a total of 152

- From LAs spread across low, mid and high deprivation LAs, measured by overall IMD scores. In the final sample all these criteria were met with the exception that only 18 LAs were recruited, with two regions (North West and South East) having only one LA included. Data cleaning removed some children from the final sample of individual cases, for example, because data was missing, but as Table 3 shows, the total available for analysis was $94 \%$ of all published CPP cases and over $91 \%$ of all LAC cases from the LAs concerned and around $12 \%$ of CPP and LAC cases nationally. In order to allow for the loss of cases in the cleaning process, in the final analysis some tables were adjusted for reduced sample size by uprating each LA's totals to create the equivalent of an $100 \%$ sample from each LA. This involves making the assumption that all missing data are distributed in the same pattern as the cleaned data, i.e. if $5 \%$ of data are missing from one LA then $5 \%$ are missing from all levels of neighbourhood deprivation. The adjusted figures then give rates which better reflect the published data for each LA and also the relative deprivation pattern in each LA. For example, the two LAs in which we had the lowest proportion of cleaned LAC data to published data are both within the third of English LAs with highest overall deprivation. Not adjusting for the lower returns would have produced underestimates of the impact of high overall deprivation on the total picture. 
FINAL DRAFT awaiting publication. Do not quote or circulate without permission.

Insert Table 3

The Index of Multiple Deprivation 2015 was published after the sample LAs had been approached and this altered the position of some LAs between mid and high deprivation. In the final sample there were 6 low deprivation LAs, containing 37\% of the children in the sample, 5 mid-deprivation LAs with $35 \%$ and 7 high deprivation LAs with $28 \%$ of the sample children.

A central purpose of the study was to test a surprising finding from the pilot study that we called the 'Inverse Intervention Law' (Bywaters et al., 2015). This was the finding that LAs that have high average deprivation also have higher overall rates of children on child protection plans or who are in out-of-home care but when you compare similar neighbourhoods in LAs that overall have high or low deprivation, the low deprivation LAs have much higher rates. We wished to establish whether this conclusion held good in a sample of LAs representative of England and a whole and at another time point: 2015 rather than 2012.

The study also included a comparison of spending on children's services in 2010-11 and 2014-15. Information about expenditure is available from 'Section 251' returns made to and published retrospectively by the DfE. On the face of it, these returns should give clear, comparable data at the LA level, broken down into a range of common factors such as expenditure on Looked-After Children or on Child Protection. However, in practice there is considerable doubt about whether LAs categorise spending in uniform ways. As a result of these doubts, we focused our attention on a small number of very broad measures: the overall spend on all children's services per head of the child population; the average spend on LAC per child who was being looked after; and the proportion of the total spend that was not spent on LAC, all of which could be broadly described as 'prevention'.

Insert Table 4

The data were prepared on Microsoft Excel files and analysed using SPSS Version 24. Summary data at the decile level were calculated for each LA, and these formed the basis of subsequent analysis. Correlation and regression techniques were used to examine for patterns with increasing deprivation decile and to assess differences between groups.

\section{Findings}

\section{Demand Factors: Deprivation}

As can be seen in Chart 1, the distribution of the child population between neighbourhoods was strongly patterned by the deprivation of the LAs concerned. Over half of all children in the high deprivation LAs came from the most deprived $20 \%$ of neighbourhoods in England (quintile 5), but few in quintile 1, a position reversed for the low deprivation LAs where fewer than one child in twenty lived in the most deprived neighbourhoods. Four high deprivation LAs had no child living in one of the least deprived $10 \%$ (decile) of neighbourhoods nationally, 2 low deprivation LAs had no children in the most deprived decile.

\section{Insert Chart 1}

Family socio-economic circumstances, as measured by neighbourhood deprivation, were strongly correlated with the proportion of children who were either on child protection plans (CPP) or were looked after (LAC) on $31^{\text {st }}$ March 2015. Children in the most deprived decile were around 13 times more likely to be on a child protection plan and 11 times more likely to be looked after than a child 
FINAL DRAFT awaiting publication. Do not quote or circulate without permission.

in the least deprived decile (Chart 2). One child in 36 in the most deprived $10 \%$ of neighbourhoods were either on a CPP or were LAC on the census day; but only one child in 426 in the least deprived neighbourhoods. Overall, in an almost identical pattern for CPP and LAC across the total sample, over $50 \%$ of children subject to these interventions were from families in the most deprived $20 \%$ of neighbourhoods, while only $5 \%$ were from the least deprived $20 \%$.

\section{Insert Chart 2}

Similar deprivation related patterns were found for sub-groups of children by gender and age group.

The deprivation gradient - the extent to which intervention rates increased with each increase in the level of deprivation - is also similar across both CPP and LAC. Although Chart 2 may look as though there is a steeper LAC gradient, this is because LAC rates are higher in each decile. In fact, for both CPP and LAC, each step increase in deprivation decile brings an approximate increase in intervention rate of about a third, with a detectable increase to three fifths between deciles 9 and 10 . There seems to be an extra penalty - in terms of child well-being or, at least, intervention rates - at extreme deprivation levels.

\section{Demand Factors: Ethnicity}

The second major factor affecting overall LA intervention rates is the proportion of children who come from different minority ethnic groups, coupled with differential intervention rates between ethnic groups. In most of the published data five ethnic categories are used for analysis: White, Mixed, Asian, Black and Other. These reflect categories used in the English population census but are in some ways unhelpfully broad (Bywaters et al., 2016b). The categories conflate or ignore issues of colour, national origin, religion, identity and ascription. However, for this purpose these issues will be set aside to be explored in more detail in a subsequent publication exploring narrower ethnic categories. As detailed population data on children by ethnic group were not available at the LSOA level for the mid-year population estimates, this part of the analysis is based on the 2011 Census.

Overall, $21 \%$ of children in the England sample were identified as being members of minority ethnic groups, although the proportion varied from $11 \%$ in the least deprived $20 \%$ of neighbourhoods to $33 \%$ in the most deprived. Minority ethnic category status is strongly associated with a greater chance of deprivation. This also varies between categories. As Table 5 shows, only $21 \%$ of 'White' children lived in the most deprived quintile of neighbourhoods, compared with around a third of all children identified as 'Mixed' or 'Asian' and over half of all 'Black' children. This major inequality in the level of deprivation of different ethnic groups (Platt, 2007) is not the subject of this paper but is the backdrop to the analysis of intervention rates.

Insert Table 5

And, of course, these proportions varied very greatly between LAs. In two London LAs, 'White' children were less than one third of the total child population, in two rural counties they comprised over $95 \%$ of all children. The proportion of 'Asian' children varied between $1 \%$ and $43 \%$ in different LAs. So it can be seen that if rates are also inequitable between these broad categories - as they are - these population differences will have a profound impact on overall LA intervention rates.

We reported for the pilot study in the West Midlands that overall rates for these broad ethnic categories may be misleading if deprivation is not also taken into account (Bywaters et al., 2016b). This is true of the representative sample as well (Table 6). Overall rates are highest for children 
FINAL DRAFT awaiting publication. Do not quote or circulate without permission.

identified as of 'Mixed' heritage, with 'Black' children having higher rates than 'White' children. Asian children's overall rate was little more than a third that of 'White' children.

Insert Table 6

However, when children living in equally deprived neighbourhoods are compared, the picture changes. In quintile 5, where more than half of all 'Black' children lived, their LAC rates were much lower than those for 'White' children. 'Mixed' heritage children had similar rates to those for 'White' children in these areas, but 'Asian; children's rates were almost 5 times lower than those for 'White' children. For 'Black' children and those categorised as 'Other' the usual social gradient is unclear, with very high rates apparent in low deprivation neighbourhoods but small numbers make these data less reliable.

Our project was not designed to explain these profound differences in rates between ethnic categories but analysis suggests that there may be higher rates for minority groups in areas where there are relatively few children from minority groups. We do not know whether higher rates reflect a higher incidence of difficult childhoods in some communities than others, higher referral rates or inequitable responses by children's services once referred. We can only reiterate the need for much greater attention to be paid to this issue.

\section{Supply Factors: The Inverse Intervention Law}

In relation to the Inverse Intervention Law, we found that the pattern was almost identical to that found in the West Midlands pilot study (Charts 3 and 4).

In each case, LAC and CPP, the overall rate was significantly higher in the high deprivation LAs as would be anticipated. However, within every deprivation quintile the rates in low deprivation LAs were substantially greater.

Insert Chart 3

Insert Chart 4

The explanation for so clear a structural relationship is not yet certain. The mixed-method case studies in LA social work teams, not reported here, designed to shed light on these patterns at the level of grass roots decision making suggest that such marked differences in rates cannot be explained by staff attitudes or behaviours. The most plausible general explanatory factor seemed likely to be the level of expenditure available in high and low deprivation LAs relative to demand and we investigated this further.

What the expenditure data show is that low deprivation LAs spend less overall per child, on average than mid deprivation LAs, which spend less than high deprivation LAs. This is as expected, as the origins of an allocation formula took deprivation into account as a key variable. Average total spend per child is set out in Table 7.

Insert Table 7

In 2010/11 average spend per child in high deprivation LAs was $80 \%$ greater than in low deprivation LAs but this premium was reduced to $55 \%$ by $2014-15$. The difficult issue to determine is whether the premium was sufficient to meet the additional demand, given the very considerable differences between LAs in the proportion of children in the $20 \%$ highest deprivation neighbourhoods where $50 \%$ of LAC and CPP lived. 
FINAL DRAFT awaiting publication. Do not quote or circulate without permission.

There is some evidence that expenditure and deprivation have an impact on the quality of children's services in ways which support the argument that the deprivation premium may no longer be great enough. In the period 2013 - early 2017, children's services in 119 LAs were inspected by Ofsted. Over $42 \%$ of low deprivation LAs received a 'good' or 'outstanding' judgement but only $10 \%$ of high deprivation LAs. This difference is statistically significant. It appears to be harder for high deprivation LAs to achieve a good grade. Moreover, on average those few high deprivation LAs that did achieve a good or outstanding outcome, spent significantly more money per child overall, than the high deprivation LAs judged to be 'inadequate'. This evidence supports the hypothesis that levels of deprivation are not adequately reflected in expenditure.

Of course, this leaves one further question hanging. If low deprivation LAs have more money to spend relative to demand why does this mean they have a higher proportion of children on CPPs or who were LAC? Might you not expect higher expenditure to result in better prevention? Evidence from elsewhere (Hood et al., 2015) suggests that high deprivation LAs, because of the greater requirement to ration scarce resources, deflect more children into community support services of one kind or another, while low deprivation LAs process children more rapidly through to the most powerful forms of intervention. And, of course, we do not know which children do best or what would be the effect of rebalancing spending away from the very expensive costs of LAC to greatly strengthened support services for the families involved.

\section{Discussion and Conclusion}

The findings of this England-based study support the importance of deprivation as a key variable in both demand for and the supply of children's services and in the generation of profound inequalities in intervention rates. Families in deprived neighbourhoods are much more likely to be subject to children's services interventions. However, In England, this is disproportionately the case for families in LAs that - overall - are responsible for areas that have relatively low deprivation. Deprivation and austerity policies are associated both with differential pressures on families and on LAs. Recent years have seen intensified stresses on families across much of the economic spectrum, accompanied, since 2010 in England, by unprecedented cuts in overall LA budgets that local prioritising of children's services has been unable to deflect. It is, therefore, not surprising that in the period 201316 , LAs with high deprivation have received substantially worse Ofsted judgements about the quality of their children's services than those with low deprivation. This should not be taken to imply that low deprivation LAs have sufficient funding to meet demand.

The study was designed to begin to put in place the building blocks for more equal chances, experiences and outcomes of children's services. It aimed to quantify inequalities in rates and identify key factors influencing those inequalities in the absence of such information in officially collected and published statistics. The major limitation of this study - and many other studies of children's services inputs and outcomes in England, is the absence of any routinely collected data or effective data linkage that provides investigators with information about the socio-economic circumstances of individual families in contact with services. Reliance on neighbourhood deprivation scores as a proxy for family circumstances is a major limitation.

A second significant limitation of the study is that it focuses only on intervention rates on a single day: $31^{\text {st }}$ March 2015, and has no information about trends or rates of intervention across childhoods. Rates change substantially over time, at different amounts in different LAs, and the speed with which children move through the system also varies between LAs and over time. None of these dimensions were the focus of this study. 
FINAL DRAFT awaiting publication. Do not quote or circulate without permission.

The third key limitation was that data are only collected and analysed here about children on CPPs or who were looked after. Further studies of the interaction of processes of referral and assessment, of which families are deflected from the system and what happens to them, and the relationship of such processes to family and LA deprivation, are required to build the bigger picture.

A fourth limitation is that high quality and detailed data about LA expenditure on children's services in England is not available. There is considerable scepticism about the precision of DfE returns as measures of relative spending on different dimensions of services provision such as early help, prevention, or child protection services.

In addition the study was not designed to identify, never mind test, alternative approaches to policy and practice that might either reduce the effects of deprivation on children or inequalities in demand and supply. Nevertheless some implications for policy and practice can be tentatively drawn from the work to date.

First, reducing structural inequalities in children's life chances, such as those identified in this research, should be a national priority for children's services as it is already for health and education. Children's services should not only seek to create equally good services for all children, as Putting Children First (DfE, 2016) proposes, but should also seek to minimise inequalities in demand for services and outcomes for children. This policy objective of greater equality in children's chances, experiences and outcomes should be embedded as a key dimension in Ofsted inspection processes.

Second, more attention should be paid across all levels of the children's services system to the impact of destitution, poverty and financial insecurity on family life. Supporting families to survive and thrive in this period of extended austerity should be a more central children services priority, as a contribution to preventing fractured and damaging relationships in families and protecting children from their consequences. This objective has to be underpinned by wider economic and social policies. It is has to inform staff education and training and be embedded in processes such as assessment and case review.

Third, better data systems are required to inform local and national governments of inequalities in the demand for and supply of services and the consequences for children. Such data systems need to include systematic information about parents and their circumstances.

Fourth, a review of the relationship between demand and the distribution of expenditure between and within LAs is overdue, and is more pressing as changes in local government financing are imminent.

Although this is study of children's services in England, the questions it raises about inequalities in child welfare and child protection systems have much wider relevance. This evidence challenges politicians, policy makers, managers, practitioners, educators and researchers to ask themselves whether such inequalities in children's life chances are acceptable and, if not, what can be done to ensure that child welfare and child protection services reduce and do not reflect or reinforce social inequality.

\section{References}

Bunting, L., McCartan, C., McGhee, J., Bywaters, P., Daniel, B., Featherstone,B., and Slater, T. (Forthcoming) Trends In Child Protection Across The UK - A Comparative Analysis.

Bywaters, P. (2016) Inequalities in child welfare: towards a new policy, research and action agenda. British Journal of Social Work, 45 (1): 6-23 doi:10.1093/bjsw/bct079 
FINAL DRAFT awaiting publication. Do not quote or circulate without permission.

Bywaters, P., Brady, G., Sparks, T., and Bos, E. (2014) Inequalities in child welfare intervention rates: the intersection of deprivation and identity, Child and Family Social Work, doi:10.1111/cfs.12161

Bywaters, P., Brady, G., Sparks, T., Bos, E., Bunting, L., Daniel, B., Featherstone, B., Morris, K. \& Scourfield, J., (2015) Exploring inequities in child welfare and child protection services: explaining the 'inverse intervention law', Children and Youth Services Review (2015), v. 57, October, pp. 98-105 doi: 10.1016/j. childyouth.2015.07.017

Bywaters, P., Brady, G., Sparks, T., and Bos, E. (2016a) Child welfare inequalities: new evidence, further questions, Child and Family Social Work, vol. 21, pp. 369-80, 2016; doi:10.1111/ cfs.12154

Bywaters, P., Kwhali, J., Brady, G., Sparks, T. and Bos, E. (2016b) Out of sight, out of mind: ethnic inequalities in child protection and out-of-home care intervention rates. British Journal of Social Work Advance Access published December 10, 2016.

Bywaters, P., Bunting, L. , Davidson, G. , Hanratty,J. , Mason, W. , McCartan, C. and Steils, N. (2016c) The relationship between poverty, child abuse and neglect: an evidence review. York: Joseph Rowntree Foundation. https://www.jrf.org.uk/report/ relationship-between-poverty-child-abuseand-neglect-evidencereview

Brown. A., Raynor, P., Benton, D. \& Lee, M. (2010) Indices of Multiple Deprivation predict breastfeeding duration in England and Wales. European Journal of Public Health, 20 (2): 231-235

Conrad, D. (2012) Deprivation-based inequalities in under-18 conception rates and the proportion of under-18 conceptions leading to abortion in England, 1998-2010, Journal of Public Health, 34 (4): 609-6

Department for Education (2012) LA and school expenditure: 2010 to 2011 financial year. https://www.gov.uk/government/statistics/local-authority-and-school-expenditure-on-educationchildrens-services-and-social-care-2010-to-2011

Department for Education (2015a) Characteristics of children in need: 2014 to 2015, Main Tables SFR41/2015. London: DfE. Available at: https://www.gov.uk/government/statistics/characteristicsof-children-in-need-2014-to-2015

Department for Education (2015b) Children looked after in England including adoption: 2014 to 2015, Main Tables SFR34/2015. London: DfE. Available at https://www.gov.uk/government/statistics/children-looked-after-in-england-including-adoption$\underline{\text { 2014-to-2015 }}$

Department for Education (2015c) S251 outturn 2014 to 2015: individual LA expenditure data. London: DfE. Available at https://www.gov.uk/government/publications/section-251-outturn-2014to-2015-data

Department for Education (2016) Putting children first: Delivering our vision for excellent children's social care. London: DfE.

Department for Education (2016). Children's services: spending and delivery, London: DfE.

Featherstone, B., Morris, K. and White, S. (2014) Reimagining Child Protection, Bristol, Policy Press.

Gove, M. (2013) Speech to the NSPCC: Getting it right for children in need. 12 November 2013 https://www.gov.uk/government/speeches/getting-it-right-for-children-in-need-speech-to-the$\underline{\text { nspcc }}$ 
FINAL DRAFT awaiting publication. Do not quote or circulate without permission.

Hood, R., Goldacre, A., Grant, R. and Jones, R. (2016) Exploring demand and provision in English child protection services. British Journal of Social Work; 46 (4): 923-941. doi: 10.1093/bjsw/bcw044

Jordan, H., Roderick, P., Martin, D. (2004) The Index of Multiple Deprivation 2000 and accessibility effects on health. Journal of Epidemiology \& Community Health, 58: 250-257

McGhee, J., Bunting, L., McCartan, C., Elliot, M., Bywaters, P. and Featherstone, B. (Forthcoming) Looking after children in the UK - convergence or divergence?

Narey, M. (2014) Making the education of social workers consistently effective. London: DfE.

National Audit Office (2016) Report by the Comptroller and Auditor General: Children in need of help or protection. London: DfE.

OECD (2016) Income inequality remains high in the face of weak recovery. Income Inequality Update, (November), 1-6. Retrieved from http://oe.cd/idd [07/02/17]

Ofsted (2016) The report of Her Majesty's Chief Inspector of Education, Children's Services and Skills 2016: Social Care. Manchester, Ofsted.

Parton, N. (2014) The Politics of Child Protection, Basingstoke, Palgrave Macmillan

Platt, L. (2007) Poverty and Ethnicity in the UK, Bristol, Policy Press.

Seebohm, F. (1968) Report of the Committee on Local Authority and Allied Social Services. Cmnd 3703. London, Her Majesty's Stationery Office.

Stanford, Sonya. (2010) 'Speaking back' to fear: Responding to the moral dilemmas of risk in social work practice. British Journal of Social Work, 40: 1065-80. 
FINAL DRAFT awaiting publication. Do not quote or circulate without permission.

Table 1: Increase in demands on children's services in England, 2009/10 - 2015-16.

\begin{tabular}{|l|l|l|c|}
\hline & $2009-10$ & $\begin{array}{l}2015- \\
16\end{array}$ & $\begin{array}{l}\text { Percentage } \\
\text { increase }\end{array}$ \\
\hline Number of referrals & 603700 & 621470 & 3 \\
\hline Number of assessments & 537400 & 571640 & 6 \\
\hline Number of children in need during the year to March 31 & 694000 & 778980 & 12 \\
\hline Number of Section 47 investigations & 89300 & 160200 & 79 \\
\hline $\begin{array}{l}\text { Number of children subject to Child Protection (CP) case } \\
\text { conferences }\end{array}$ & 43900 & 71400 & 63 \\
\hline Number of children on a Child Protection plan during the year & 44300 & 63310 & 43 \\
\hline Number of children looked after during the year to March 31 & 88250 & 100810 & 14 \\
\hline
\end{tabular}


FINAL DRAFT awaiting publication. Do not quote or circulate without permission.

Table 2: Percentage changes in patterns of referrals, assessments, investigations, case conferences and child protection plans

\begin{tabular}{|l|c|c|c|}
\hline & $\begin{array}{l}2009- \\
10\end{array}$ & $\begin{array}{l}2015- \\
16\end{array}$ & $\begin{array}{l}\text { Percentage } \\
\text { change }\end{array}$ \\
\hline Ratio of assessments to referrals (\%) & 89 & 92 & 3 \\
\hline Ratio of Section 47 investigations to referrals (\%) & 15 & 26 & 74 \\
\hline Ratio of children on CP case conferences to S47 investigations (\%) & 49 & 45 & -9 \\
\hline Ratio of children on CP plans to children at CP case conferences (\%) & 101 & 89 & -12 \\
\hline Ratio of children on CP plans to S47 investigations (\%) & 50 & 40 & -20 \\
\hline
\end{tabular}


FINAL DRAFT awaiting publication. Do not quote or circulate without permission.

\begin{tabular}{|l|l|l|l|l|}
\hline Table 3: The England Sample \\
\hline At 31.3.15 & $\begin{array}{l}\text { Population } \\
0-17\end{array}$ & $\begin{array}{l}\text { Children in } \\
\text { Need }\end{array}$ & $\begin{array}{l}\text { Children on } \\
\text { Child } \\
\text { Protection } \\
\text { Plans }\end{array}$ & $\begin{array}{l}\text { Looked After } \\
\text { Children }\end{array}$ \\
\hline England - Published Data & 11591701 & 391000 & 49700 & 69540 \\
\hline Sample - Published Data & 1432180 & 52179 & 6716 & 8865 \\
\hline Sample - Reported Data & & 53803 & 6708 & 8854 \\
\hline Sample - Cleaned Data & & 46839 & 6310 & 8090 \\
\hline Sample as \% of England Published & 12.4 & 13.3 & 13.5 & 12.7 \\
\hline Sample as \% of England Published & & 12.0 & 12.7 & 11.6 \\
\hline
\end{tabular}


FINAL DRAFT awaiting publication. Do not quote or circulate without permission.

\begin{tabular}{|c|c|c|}
\hline \multicolumn{3}{|c|}{$\begin{array}{l}\text { Table 4: Child (0-17) Population in Low, } \\
\text { Mid and High Deprivation LAs in the } \\
\text { England Sample }\end{array}$} \\
\hline & Child Population & $\begin{array}{l}\text { As \% of } \\
\text { England }\end{array}$ \\
\hline Low & 528404 & 4.6 \\
\hline Mid & 495963 & 4.3 \\
\hline High & 407813 & 3.5 \\
\hline
\end{tabular}


FINAL DRAFT awaiting publication. Do not quote or circulate without permission.

\begin{tabular}{|c|c|c|c|c|c|c|}
\hline $\begin{array}{l}\text { Deprivation } \\
\text { Quintiles }\end{array}$ & 1 & 2 & 3 & 4 & 5 & Total \\
\hline White & 21 & 20 & 21 & 17 & 21 & 100 \\
\hline Mixed & 13 & 14 & 18 & 20 & 35 & 100 \\
\hline Asian & 12 & 16 & 19 & 21 & 32 & 100 \\
\hline Black & 4 & 7 & 13 & 25 & 52 & 100 \\
\hline Other & 6 & 10 & 19 & 28 & 37 & 100 \\
\hline All & 19 & 19 & 20 & 18 & 24 & 100 \\
\hline
\end{tabular}


FINAL DRAFT awaiting publication. Do not quote or circulate without permission.

\begin{tabular}{|l|c|c|c|c|c|c|}
\hline \multicolumn{7}{|c|}{ Table 6: LAC rates by deprivation quintile and ethnic category, England sample. } \\
\hline $\begin{array}{l}\text { Deprivation } \\
\text { Quintile }\end{array}$ & 1 & 2 & 3 & 4 & 5 & ALL \\
\hline White & 15 & 28 & 42 & 77 & 162 & 64 \\
\hline Mixed & 27 & 47 & 62 & 103 & 164 & 99 \\
\hline Asian & 7 & 18 & 15 & 21 & 34 & 22 \\
\hline Black & 12 & 97 & 62 & 96 & 92 & 87 \\
\hline Other & 46 & 90 & 52 & 41 & 111 & 74 \\
\hline
\end{tabular}


FINAL DRAFT awaiting publication. Do not quote or circulate without permission.

Table 7: Percentage reduction in total children's services spend per child in England 2010/11 to 2014/15, by LA deprivation.

\begin{tabular}{|l|l|l|l|l|}
\hline & & $\begin{array}{l}\text { Ave. Spend } \\
\text { per Child } \\
2010 / 11(f)\end{array}$ & $\begin{array}{l}\text { Ave. Spend } \\
\text { per Child } \\
2014 / 15(f)\end{array}$ & $\begin{array}{l}\text { Reduction } \\
(\%) \text { in spend } \\
\text { per child }\end{array}$ \\
\hline England & Low Deprivation & 708 & 655 & 7 \\
& Mid Deprivation & 996 & 885 & 11 \\
& High Deprivation & 1280 & 1017 & 21 \\
\hline
\end{tabular}


FINAL DRAFT awaiting publication. Do not quote or circulate without permission.

Figure 1

\begin{tabular}{|c|c|c|}
\hline $\begin{array}{l}\text { Demand Factors } \\
\text { Contributory structural factors } \\
\text { associated with levels of need, for } \\
\text { example: } \\
\text { - Socio-economic circumstances } \\
\text { of families } \\
\text { - Community strengths } \\
\text { - Neighbourhood conditions } \\
\text {-Demographic factors including } \\
\text { ethnicity }\end{array}$ & Interact with & $\begin{array}{l}\quad \text { Supply Factors } \\
\text { Contributory structural factors } \\
\text { associated with the provision of } \\
\text { services, for example: } \\
\text { - National legal frameworks, policies, } \\
\text { structures, cultures } \\
\text { - Local policies, priorities, practices } \\
\text { and cultures } \\
\text {-The level and distribution of } \\
\text { expenditure and resources }\end{array}$ \\
\hline \multicolumn{3}{|c|}{ To produce } \\
\hline
\end{tabular}


FINAL DRAFT awaiting publication. Do not quote or circulate without permission.

\section{Chart 1}

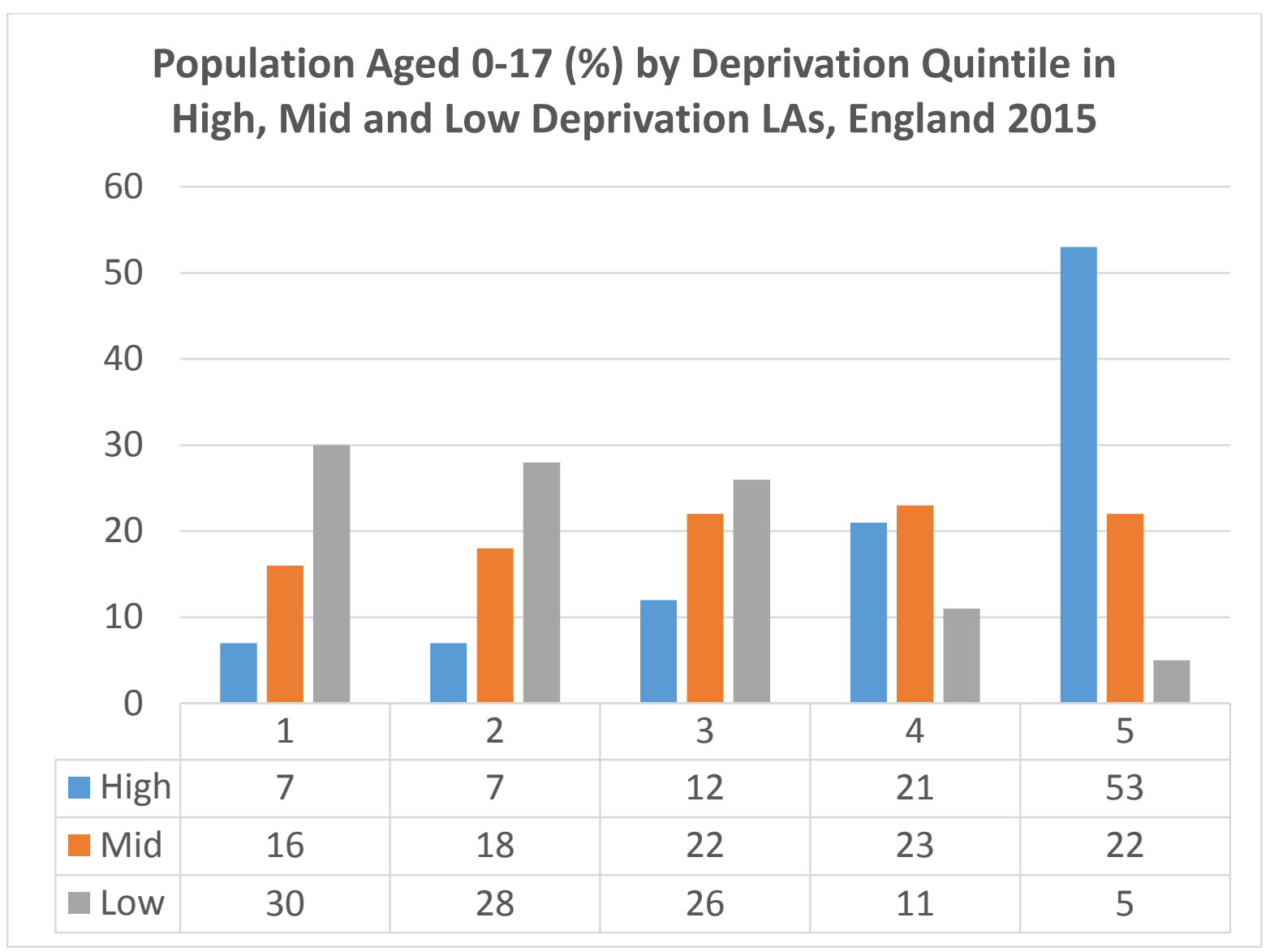


FINAL DRAFT awaiting publication. Do not quote or circulate without permission.

\section{Chart 2}

\section{England CPP and LAC Rates by Deprivation Decile, England IMD, Adjusted, 31.3.15}

180

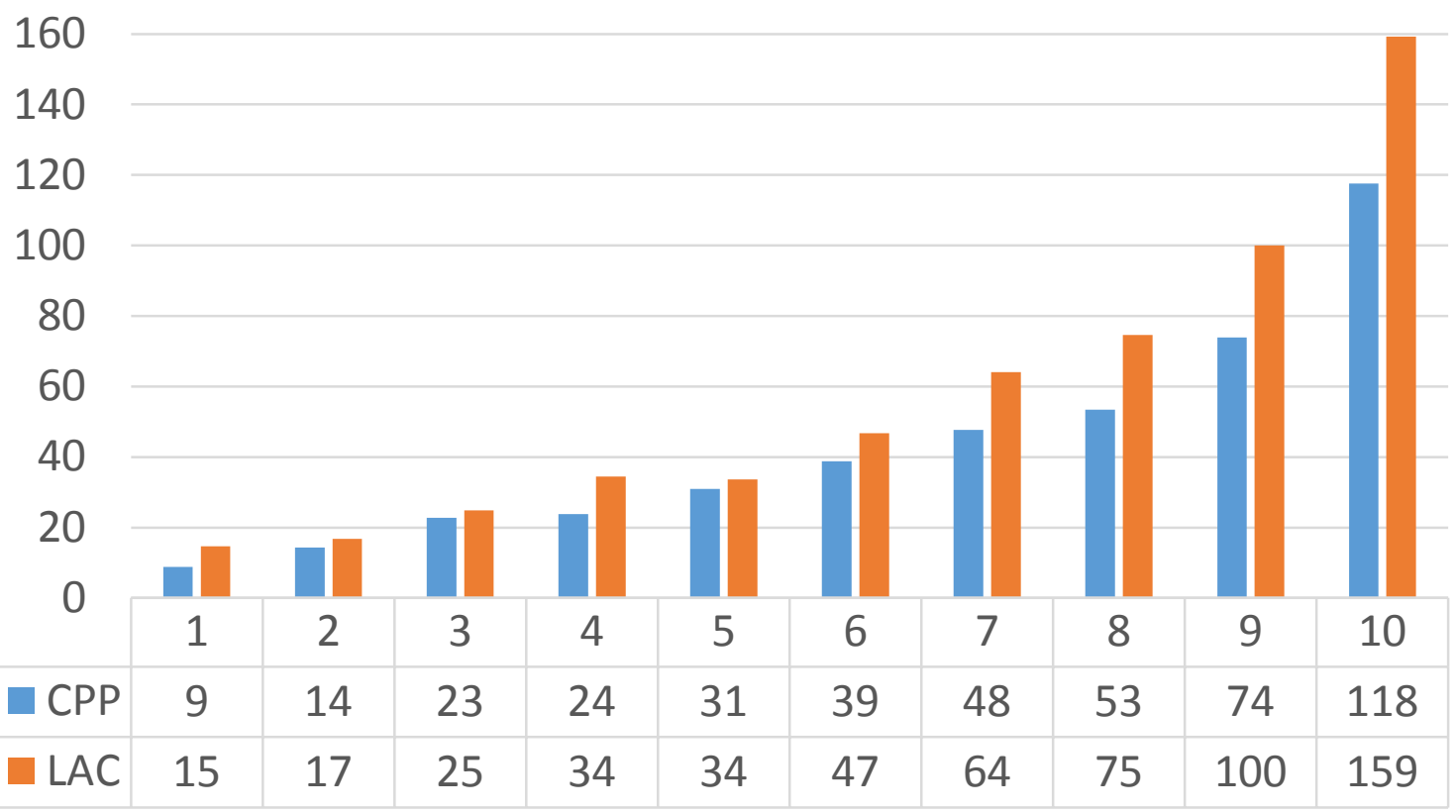


FINAL DRAFT awaiting publication. Do not quote or circulate without permission.

\section{Chart 3}

Inverse Intervention Law: LAC Rates in High and Low Deprivation LAs, England Sample, Unadjusted, 2015 180

160

140

120

100

80

60

40

20

\begin{tabular}{|c|c|c|c|c|c|c|}
\hline v & 1 & 2 & 3 & 4 & 5 & All \\
\hline - High IMD & 11 & 17 & 32 & 54 & 105 & 73 \\
\hline Low IMD & 15 & 27 & 43 & 81 & 165 & 40 \\
\hline
\end{tabular}


FINAL DRAFT awaiting publication. Do not quote or circulate without permission.

\section{Chart 4}

\section{Inverse Intervention Law: CPP rates in High and Low Deprivation LAs}

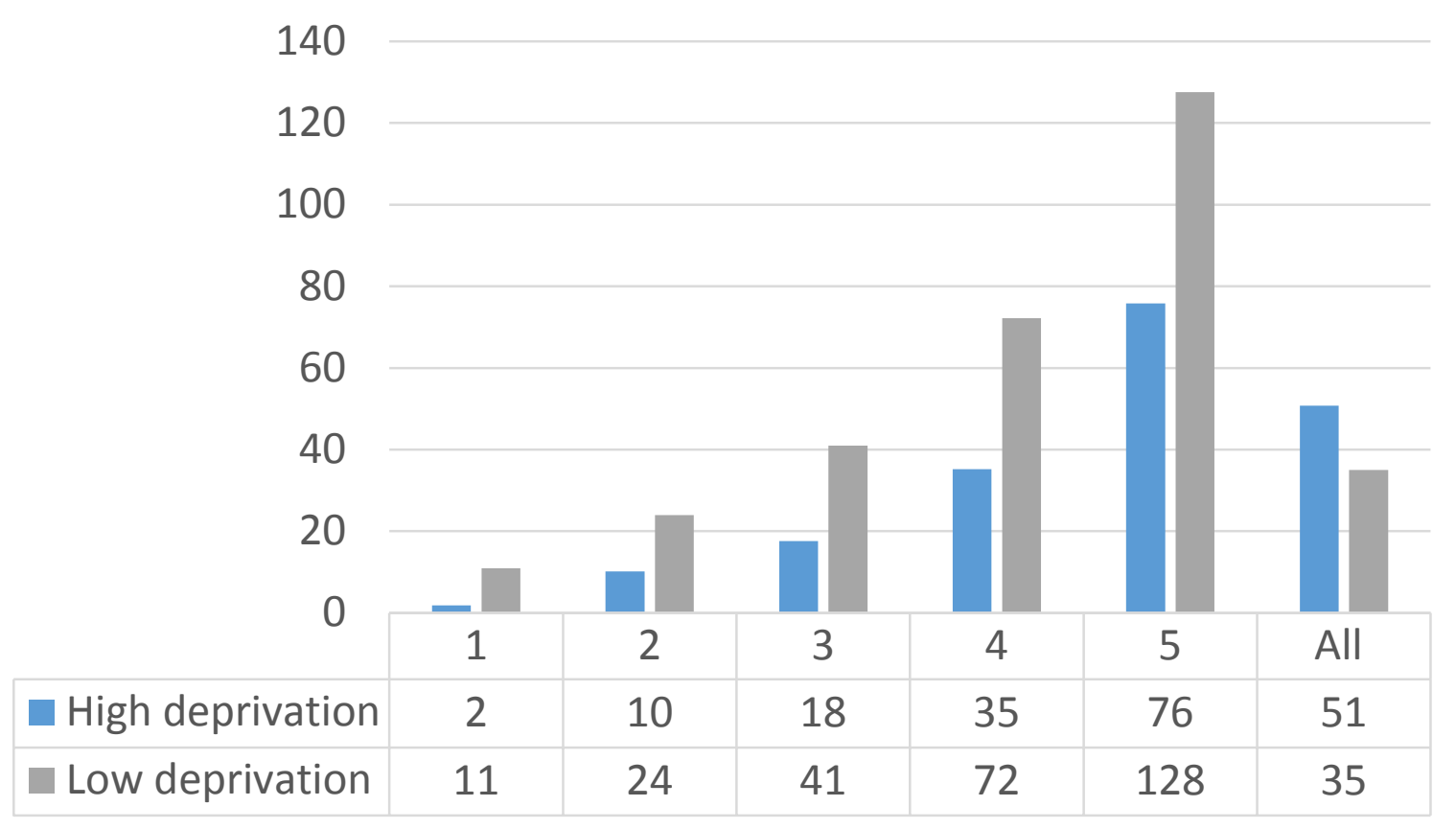

